\title{
Fe deficiency induction in Poncirus trifoliata rootstock growing in nutrient solution changes its performance after transplant to soil
}

\author{
Florinda Gama ${ }^{a}$, Teresa Saavedra ${ }^{a}$, Isabel Díaz ${ }^{\mathrm{b}}$, María del Carmen Campilloc, \\ Amarilis de Varennes ${ }^{\mathrm{d}}$, Amílcar Duarte ${ }^{\mathrm{a}}$, Maribela Pestana ${ }^{\mathrm{a}}$, Pedro José Correia ${ }^{\mathrm{a}, *}$ \\ a ICAAM, Universidade do Algarve, FCT, Edf 8, Campus de Gambelas, 8005-139 Faro, Portugal \\ b Departamento de Ingeniería Aeroespacial, ETSIA, Universidad de Sevilla, Ctra. Utrera km 1, 41013 Sevilla, Spain \\ c Departamento de Agronomía, Universidad de Córdoba, Edificio C4, Campus de Rabanales, 14071 Córdoba, Spain \\ d CEER, Instituto Superior de Agronomia-Universidade de Lisboa, Tapada da Ajuda, 1349-017 Lisboa, Portugal
}

\section{A R T I C L E I N F O}

\section{Article history:}

Received 20 June 2014

Received in revised form 4 November 2014

Accepted 6 November 2014

Available online 11 December 2014

\section{Keywords:}

Calcareous soil

Ferric chelate redutase

Iron chlorosis

Nutrients

SPAD values

\begin{abstract}
A B S T R A C T
The absence of iron (Fe) in the nutrient solution induces several physiological and morphological adaptations in the roots of Poncirus trifoliata, a citrus rootstock, thereby modifying its overall nutritional status. Whether these changes are advantageous when plants are transplanted to calcareous soils needs to be assessed. To achieve this objective a two-phase experiment was established, first in nutrient solution (phase I) then in pots containing different soils (phase II). In phase I, P. trifoliata L. Raf. plants were grown in Hoagland's solution with $120 \mu \mathrm{M}$ of Fe (Fe120 treatment) or without (Fe0 treatment). At the end of phase I (87 days), Fe-chlorotic plants had less chlorophyll in apical younger leaves, root tips were swollen and their FC-R activity was enhanced, typical responses to Fe-stress. Chlorotic plants had less Fe compared to control plants, but accumulated more $\mathrm{Cu}$ and $\mathrm{Zn}$. In contrast the root to shoot ratio (dry weight) and the amounts of macronutrients were not affected by Fe chlorosis. In phase II, plants of both treatments were transplanted to pots containing a calcareous (C) or a non-calcareous (nC) soil resulting in four treatments: Fe0nC, Fe120nC, Fe0C and Fe120C. From the end of phase I until the end of the experiment (353 days), the calcareous soil negatively affected the overall nutritional balance in both $\mathrm{Fe} 0$ and $\mathrm{Fe} 120$ treatments. Apparently, the ability to change metal homeostasis in particular $\mathrm{Cu}$, as a $\mathrm{Fe}$-stress response was maintained in plants grown in non-calcareous soil. Moreover, the previous induction of physiological and morphological adaptations to Fe depletion alleviated the iron chlorosis symptoms caused by soil carbonates. These results may point to the utilization of internal stress signalling as a tool to cope with different soil conditions.
\end{abstract}

(c) 2014 Elsevier B.V. All rights reserved.

\section{Introduction}

Iron (Fe) chlorosis is an important nutritional disorder in fruit trees that results from a poor uptake and transport of Fe within the plant. It normally occurs in calcareous soils due to the large amount

Abbreviations: ACCE, active calcium-carbonate equivalent; BPDS, bathophenantrolinedisulfonate; $C$, calcareous soil; $\mathrm{CEC}_{c}$, cation exchange capacity expressed in centimoles of positive charge per unit exchange; Chl, chlorophyll; EC, electrical conductivity; FC-R, ferric chelate redutase; $\mathrm{Fe}_{\mathrm{d}}$, dithionite-extractable iron; $\mathrm{Fe}_{\mathrm{ox}}$, acid ammonium oxalate extractable iron; $\mathrm{nC}$, non-calcareous soil; OM, organic matter.

* Corresponding author. Tel.: +351289 800900.

E-mail addresses: fmgama@ualg.pt (F. Gama),tmr.saavedra@gmail.com (T. Saavedra), isabeldiaz@us.es (I. Díaz), ef1cagam@uco.es (M.d.C.Campillo), adevarennes@isa.utl.pt (A. de Varennes), aduarte@ualg.pt (A. Duarte), fpestana@ualg.pt (M. Pestana), pcorreia@ualg.pt (P.J. Correia). of bicarbonate ion and high $\mathrm{pH}$ which varies between 7.5 and 8.5. In the Mediterranean region, between 20\% and 50\% of fruit trees are affected by this deficiency resulting in a low photosynthetic rate, limited plant growth, nutritional imbalances, poor fruit quality and yield (Pestana et al., 2003; Rombolà and Tagliavini, 2006; ÁlvarezFernández et al., 2011). Visible symptoms start in young leaves as an interveinal chlorosis and then progress into an overall chlorosis with sharp decreases in leaf chlorophyll. To solve this problem in orchards, farmers apply different types of Fe salts: inorganic Fecompounds, natural Fe-complexes and Fe-chelates (Abadía et al., 2011), but the latter are the most used and effective (Lucena, 2009). Every year large amounts of synthetic chelates are applied to soil or leaves, even in the nursery, to increase the availability of Fe in plant tissues in high valuable crops, like peach, pear, apple, grapevines and citrus.

In citrus, tolerance to Fe chlorosis is highly variable (Castle et al., 2009). For example, sour orange (Citrus aurantium L.), rough lemon 
(Citrus jambhiri Lush.), Rangpur lime (Citrus limonia Osb.), Volkamer lemon (Citrus volkameriana Ten. and Pasq.) and Cleopatra mandarin (Citrus reshni hort ex Tanaka) are tolerant while trifoliate orange (Poncirus trifoliata L. Raf.), and its hybrids like Troyer and Carrizo citranges (Citrus sinensis L. Osb. $\times$ P. trifoliata L. Raf.) are susceptible to this deficiency (Pestana et al., 2011a). However, citranges are the most widely used rootstocks even in calcareous soils due to the agronomic interest such as tolerance to several pests and diseases such as Tristeza. Some genotypes are able to increase Fe uptake by enhancing proton extrusion, which acidifies the root apoplast, and the activity of the ferric chelate reductase (FC-R) as found in Strategy I plants (Abadía et al., 2011). Several studies have focussed on the differences in root responses to Fe deficiency among citrus species (Chouliaras et al., 2004; Pestana et al., 2005, 2011a) and concluded that the rootstock $P$. trifoliata is one of the most susceptible to Fe chlorosis. In experiments conducted in nutrient solutions, the activity of the root FC-R was low in the absence of Fe but it was incremented if small amounts of Fe were added to the nutrient solution (Pestana et al., 2012), as also reported for Prunus sp. (Gogorcena et al., 2004; Jiménez et al., 2008). However, the activation of the FC-R may revert if more Fe is added, resulting in a regreening of chlorotic plants (Pestana et al., 2011b). This "on-off" regulation has direct implications on root Fe uptake but also on the balance of macro and micronutrients among different plant organs, in particular on Fe homeostasis with other metals like $\mathrm{Cu}$ and $\mathrm{Zn}$ (Pestana et al., 2013), and Mn, as found in leaves of the Prunus rootstock GF 677 (Jiménez et al., 2009).

In spite of the current knowledge on the response mechanisms to Fe deficiency exhibited by $P$. trifoliata grown in nutrient solutions, there is no information on how these plants react when transplanted to soils. Such study may allow the optimization of nutritional inputs at the nursery stage and anticipate nutritional constraints which might occur in calcareous soils. It may also provide new insights on the effectiveness of internal Fe pools and the impact of physiological and morphological stress-adaptations when facing a new environment. In this work, we examine the behaviour of plants with contrasting levels of Fe (grown in nutrient solutions with and without $\mathrm{Fe}$ ) when transplanted to two different soils: non-calcareous and calcareous.

\section{Materials and methods}

\subsection{Growth of plants in nutrient solution (phase I)}

One-year old $P$. trifoliata (L.) Raf. rootstocks were acquired in a commercial nursery. Plants were removed from the substrate and the roots were thoroughly washed and disinfected by immersion in a solution with $2 \mathrm{~g} \mathrm{~L}^{-1}$ fosethyl-aluminium for $2 \mathrm{~h}$.

The experiment started on the 12th of April and at this stage, the plants had the following characteristics (mean \pm standard error): height $31.3 \pm 1.6 \mathrm{~cm}$; number of leaves $20 \pm 2$; shoot dry weight $2.2 \pm 0.1 \mathrm{~g}$; root dry weight $6.5 \pm 0.3 \mathrm{~g}$ Forty plants were grown for 87 days in full-strength Hoagland's nutrient solution with the following composition (in $\mathrm{mM}$ ): $5 \mathrm{Ca}\left(\mathrm{NO}_{3}\right)_{2} \cdot 4 \mathrm{H}_{2} \mathrm{O}, 5 \mathrm{KNO}_{3}$, $1 \mathrm{KH}_{2} \mathrm{PO}_{4}, 2 \mathrm{MgSO}_{4} \cdot 7 \mathrm{H}_{2} \mathrm{O}$, and (in $\mu \mathrm{M}$ ): $46 \mathrm{H}_{3} \mathrm{BO}_{3}, 0.8 \mathrm{ZnSO}_{4} \cdot 7 \mathrm{H}_{2} \mathrm{O}$, $0.4 \mathrm{CuSO}_{4} \cdot 5 \mathrm{H}_{2} \mathrm{O}, 9 \mathrm{MnCl}_{2} \cdot 4 \mathrm{H}_{2} \mathrm{O}$ and $0.02\left(\mathrm{NH}_{4}\right) 6 \mathrm{Mo}_{7} \mathrm{O}_{27} \cdot \mathrm{H}_{2} \mathrm{O}$, without $\mathrm{Fe}$ ( $\mathrm{Fe} 0$ treatment) or with $120 \mu \mathrm{M}$ of $\mathrm{Fe}$ (Fe120 treatment). Iron was added to the solutions as Fe (III)-EDDHA. Each Fe treatment consisted of 20 plants, in a total of 40 plants distributed in eight containers $(20 \mathrm{~L})$ which were placed in a complete randomized design.

During this experimental period, plants were grown in a glasshouse under natural photoperiod conditions and air temperature $\leq 25^{\circ} \mathrm{C}$. The nutrient solutions were constantly aerated and the $\mathrm{pH}$ adjusted to $6.0 \pm 0.1$. At the beginning of the experiment the electrical conductivity (EC) was $2.2 \mathrm{dS} \mathrm{m}^{-1}$. The solutions were monitored periodically, every two days and replaced when the EC value was less than $2.0 \mathrm{dS} \mathrm{m}^{-1}$.

\subsection{Growth of plants in soils (phase II)}

At the end of phase I, plants were around $36 \pm 3 \mathrm{~cm}$ tall, irrespective of treatment. Ten plants from each Fe treatment were transplanted to $21 \mathrm{~cm}$-diameter pots containing $4600 \mathrm{~g}$ of a calcareous soil (C) and a non-calcareous soil (nC), both mixed with vermiculite and organic matter $(\mathrm{OM})$ in a 2:1:1 proportion to improve their properties. A NPK fertilizer (7:21:21) was also applied to ensure non-limiting amounts of these elements throughout the experimental period of phase II.

Four treatments were imposed. The Fe0nC and Fe120nC, corresponding to plants that grew in 0 or $120 \mu \mathrm{M}$ Fe in phase I and then on the non-calcareous soil ( $\mathrm{nC}$ ). The Fe0C and Fe120C treatments refers to plants that grew in 0 or $120 \mu \mathrm{M}$ Fe in phase I and then were transplanted to the calcareous soil (C) in phase II.

To characterize the soils, three random samples of each soil mixed with amendments were oven-dried for $48 \mathrm{~h}$ at $40^{\circ} \mathrm{C}$ then passed through a $2-\mathrm{mm}$ sieve. The $\mathrm{pH}$ was evaluated in $1: 2.5$ soil-water suspensions, and EC was measured with a conductivity meter (portable WTW conductivity meter) in 1:5 soil-water suspensions. Organic carbon was analysed by oxidation using dichromate (Walkley and Black, 1934). Active Ca-carbonate equivalent (ACCE) or active lime was extracted with ammonium oxalate and quantified by titration with potassium permanganate (Drouineau, 1942). Phosphorus (P) was extracted using a solution of sodium bicarbonate $\mathrm{pH} 8.5$ (Olsen and Sommers, 1982) and the content in the extracts was quantified colorimetrically. Potassium (K) was extracted using a solution of ammonium acetate (Riehm, 1958) and determined by flame spectrometry. Cation exchange capacity was determined by the barium chloride-triethanolamine method (Mehlich, 1984). The citrate/bicarbonate/dithionite-extractable Fe $\left(\mathrm{Fe}_{\mathrm{d}}\right)$ was determined according to Mehra and Jackson (1960) except that extraction was carried out at $25^{\circ} \mathrm{C}$ for $16 \mathrm{~h}$ and provides a measure of the $\mathrm{Fe}$ in all Fe oxides. The acid $\mathrm{NH}_{4}$ oxalate extractable $\mathrm{Fe}\left(\mathrm{Fe}_{\mathrm{ox}}\right)$ which provides an estimate for the Fe in poorly crystalline Fe oxides, was determined according to Schwertmann (1964) except that the soil: solution ratio was 1:200 in order to prevent a significant $\mathrm{pH}$ increase in the extractant due to the presence of carbonate. Soil texture was determined by the hydrometer method (Bouyoucos, 1962). The calcareous soil (C) had significantly higher $\mathrm{pH}$ value, ACCE and also higher levels of $\mathrm{P}$ and $\mathrm{K}$ compared to the non-calcareous soil (Table 1). Extractable Fe, measured by $\mathrm{Fe}_{\mathrm{ox}}$ was similar in both soils; however the ratio $\mathrm{Fe}_{\mathrm{ox}} / \mathrm{ACCE}$ was significantly lower in C, confirming its ability to induce iron chlorosis in plants.

Plants were transplanted by the end of July (after 87 days in the nutrient solutions), and the pots placed outdoors at Campus de Gambelas, Faro, Portugal ( $\left.37^{\circ} 02^{\prime} 40^{\prime} \mathrm{N}, 7^{\circ} 58^{\prime} 27^{\prime} \mathrm{W}\right)$. The site has a typical Mediterranean climate, with hot dry summers and mild winters. Mean air temperature ranges between $12^{\circ} \mathrm{C}$ in January and $24.2^{\circ} \mathrm{C}$ in July and mean precipitation ranges between $114.1 \mathrm{~mm}$ in December and $1.8 \mathrm{~mm}$ in July. Drip irrigation took place daily at a rate of $0.4 \mathrm{~L}$ per pot. The $\mathrm{pH}$ of the irrigation water was 6.5 and the electrical conductivity $0.3 \mathrm{dS} \mathrm{m}^{-1}$.

As $P$. trifoliata is a deciduous rootstock, leaves were gradually shed during winter and a spring flush started approximately 253 days (end of March) after transplant from the nutrient solutions. At the beginning of April, a clear differentiation could be made between young apical and mature basal leaves according to their position in the stem. 
Table 1

Characteristics of the two soils used in phase II.

\begin{tabular}{|c|c|c|c|}
\hline \multirow[t]{2}{*}{ Parameter $^{\mathrm{a}}$} & \multicolumn{2}{|l|}{ Soil } & \multirow[t]{2}{*}{$P$} \\
\hline & Non-calcareous & Calcareous & \\
\hline $\mathrm{ACCE}\left(\mathrm{g} \mathrm{kg}^{-1}\right)$ & $7 \pm 0.40$ & $104 \pm 0.40$ & **** \\
\hline $\mathrm{pH}$ & $6.18 \pm 0.02$ & $7.79 \pm 0.04$ & *** \\
\hline $\mathrm{EC}\left(\mathrm{dS} \mathrm{m}^{-1}\right)$ & $0.64 \pm 0.24$ & $0.48 \pm 0.01$ & ns \\
\hline $\mathrm{OM}\left(\mathrm{g} \mathrm{kg}^{-1}\right)$ & $11.7 \pm 1.05$ & $15.2 \pm 1.99$ & ns \\
\hline Clay $\left(\mathrm{g} \mathrm{kg}^{-1}\right)$ & $222 \pm 6.65$ & $203 \pm 13.3$ & ns \\
\hline $\mathrm{CEC}_{\mathrm{c}}\left(\mathrm{cmol} \mathrm{kg}^{-1}\right)$ & $133 \pm 4.17$ & $154 \pm 8.33$ & ns \\
\hline Olsen $\mathrm{P}\left(\mathrm{mg} \mathrm{kg}^{-1}\right)$ & $34 \pm 3.56$ & $54 \pm 4.25$ & $* *$ \\
\hline $\mathrm{K}\left(\mathrm{mg} \mathrm{kg}^{-1}\right)$ & $261 \pm 1.25$ & $292 \pm 4.26$ & $* *$ \\
\hline \multicolumn{4}{|l|}{ Extractable Fe: } \\
\hline $\mathrm{Fe}_{\mathrm{d}}\left(\mathrm{mg} \mathrm{kg}^{-1}\right)$ & $12500 \pm 650.6$ & $6400 \pm 131.8$ & $* *$ \\
\hline $\mathrm{Fe}_{\mathrm{ox}}\left(\mathrm{mg} \mathrm{kg}^{-1}\right)$ & $837 \pm 29.9$ & $998 \pm 56.5$ & ns \\
\hline$\left(\mathrm{Fe}_{\mathrm{ox}} / \mathrm{ACCE}\right)^{*} 10^{4}$ & $1260 \pm 41.8$ & $96 \pm 5.65$ & $* * *$ \\
\hline
\end{tabular}

a Mean \pm standard error.

ACCE, active Ca-carbonate equivalent; $\mathrm{CEC}_{c}$, cation exchange capacity expressed in centimoles of positive charge per unit exchange; EC, electrical conductivity of the 1:5 soil: water extract; $\mathrm{Fe}_{\mathrm{d}}$, citrate/bicarbonate/dithionite-extractable $\mathrm{Fe}$; $\mathrm{Fe}_{\mathrm{ox}}$, acid $\mathrm{NH}_{4}$ oxalate extractable Fe; ns: not significant; OM, organic matter; ${ }^{* *}$ or ${ }^{* * *}$ indicate, respectively: significant for $P<0.01$ or $P<0.001$ (ANOVA; $F$ test); $n=3$.

\subsection{Plant growth and degree of chlorosis}

The degree of chlorosis was determined in fully expanded young (apical) leaves and in mature (basal) leaves using a SPAD-502 apparatus (Minolta Corp., Osaka, Japan). SPAD values were converted to total leaf chlorophyll ( $\mathrm{Chl}$ ) concentration, using a calibration curve previously obtained (Correia et al., 2014).

At the end of phase I, ten plants per treatment were separated into roots and shoots and after phase II (as stems were bigger) plants were also separated into roots, stems and leaves. Each plant material was washed with tap water, followed by distilled water containing a non-ionic detergent, then with $0.01 \mathrm{M} \mathrm{HCl}$ and finally rinsed three times with distilled water. Samples were dried to constant weight at $60^{\circ} \mathrm{C}$. Height, dry weights and root/shoot ratios were registered at the end of each phase.

\subsection{Mineral composition}

Dried plant material was ground and ashed at $450{ }^{\circ} \mathrm{C}$ followed by digestion in an acidic solution $(\mathrm{HCl} 1 \mathrm{M})$. The concentration of $\mathrm{K}, \mathrm{Ca}, \mathrm{Mg}, \mathrm{Mn}, \mathrm{Zn}, \mathrm{Cu}$ and Fe was determined by atomic absorption spectrophotometry (Pye Unicam, Cambridge, UK) following standard methods (A.O.A.C., 1990). Phosphorus was analysed colorimetrically by the molybdo-vanadate method at $375 \mathrm{~nm}$ Nitrogen was analysed by the Kjeldahl method. Nutrient concentrations are expressed on a dry weight (DW) basis for each plant material. The nutrient contents were calculated by multiplying the DW by the concentrations.

\subsection{Activity of the root FC-R}

The activity of the root FC-R was measured by the formation of the Fe(II)-bathophenantrolinedisulfonate (BPDS) complex from Fe(III)-EDTA (Bienfait et al., 1983). Measurements were performed at days 48,78 and 87 of phase I and at the end of phase II. For this purpose, roots were gently washed with distilled water. At least nine root tips were excised (approximately $2 \mathrm{~cm}$ each) with a razor blade from each of three plants per treatment. The root tips with about $20.8 \pm 5 \mathrm{mg}$ fresh weight (FW) were incubated in an Eppendorf tube in the dark with $900 \mu \mathrm{L}$ of micronutrient-free half strength Hoagland's nutrient solution, containing $300 \mu \mathrm{M}$ BPDS, $500 \mu \mathrm{M}$ Fe(III)-EDTA and 2 mM MES at pH 6.0. Readings were done after $2 \mathrm{~h}$ of incubation. The reducing capacity was determined by measuring the concentration of the Fe (II)-BPDS complex at $520 \mathrm{~nm}$
Table 2

Plant height, biomass determined at the end of phase I ( 87 days in nutrient solution). Ferric chelate reductase (FC-R) activity was also measured 48 and 78 days after the beginning of the experiment.

\begin{tabular}{|c|c|c|c|}
\hline & \multicolumn{2}{|l|}{ Treatments } & \\
\hline & $\mathrm{Fe} 0$ & Fe120 & \\
\hline Height $(\mathrm{cm})$ & $45 \pm 4$ & $49 \pm 2$ & ns \\
\hline \multicolumn{4}{|l|}{ Dry weight: } \\
\hline Shoot (g) & $6.27 \pm 0.75$ & $4.30 \pm 0.31$ & ** \\
\hline $\operatorname{Root}(\mathrm{g})$ & $3.01 \pm 0.37$ & $2.05 \pm 0.10$ & $*$ \\
\hline Root/shoot & $0.49 \pm 0.04$ & $0.49 \pm 0.04$ & ns \\
\hline \multicolumn{4}{|c|}{$\begin{array}{l}\text { FC-R: } \\
\left(\mathrm{nmol} \mathrm{Fe}(\mathrm{II}) \mathrm{min}^{-1} \mathrm{~g}^{-1} \mathrm{FW}\right)\end{array}$} \\
\hline 48 days & $3.85 \pm 0.60$ & $4.87 \pm 0.68$ & ns \\
\hline 78 days & $2.67 \pm 0.12$ & $2.49 \pm 0.24$ & ns \\
\hline 87 days & $4.43 \pm 0.62$ & $2.69 \pm 0.24$ & $* *$ \\
\hline
\end{tabular}

Mean \pm standard error; FW, fresh weight; ${ }^{*},{ }^{* *}$ or ${ }^{* * *}$ indicate, respectively: significan for $P<0.05$ or $P<0.01$ or $P<0.001$ (ANOVA; F test); at least $n=5$.

in a spectrophotometer (Bienfait et al., 1983). An extinction coefficient of $22.14 \mathrm{mM} \mathrm{cm}^{-1}$ was used. Blank controls without root segments were also used to correct for any unspecific Fe reduction. The FC-R activity was expressed on a root FW basis.

\subsection{Statistical analysis}

In phase I, the effects of Fe treatments were evaluated by analysis of variance (ANOVA; $F$ Test). In phase II, main effects and interactions of substrate $(\mathrm{S})$, Fe treatments $(\mathrm{Fe})$ and plant organs $(\mathrm{O})$ were also assessed. When ANOVA yielded a significant $F$ value, the individual means were compared using the Duncan Multiple Range Test (DMRT) at $P<0.05$. All the determinations were obtained with randomly chosen plants. Data were analysed statistically using SPSS ${ }^{\circledR}$ (Release 18.0, SPSS Inc, Chicago, IL) software package.

\section{Results}

\subsection{Phase I}

Plants grown without $\mathrm{Fe}(\mathrm{Fe} 0)$ started showing symptoms in the young leaves after 35 days of growth and Chl values decreased throughout phase I, whereas plants grown in Fe120 remained green and showed an increase in Chl during all this phase (Fig. 1). In mature leaves, Chl values were similar and they had no symptoms of Fe chlorosis.

In spite of the differences in leaf $\mathrm{Chl}, \mathrm{Fe} 0$ plants grew well as shoot height $(34 \mathrm{~cm})$ and root dry weight $(4 \mathrm{~g})$ were similar in all 40 plants at the end of phase I. Shoot dry weight was even significantly higher in these plants (Table 2). The FC-R activity decreased from 4.87 to 2.69 in Fe120 plants while in Fe0, root FC-R increased from 3.85 to $4.43 \mathrm{nmol} \mathrm{Fe}$ (II) $\mathrm{min}^{-1} \mathrm{~g}^{-1}$ of FW between days 48 and 87 , respectively. At the end of this phase, the FC-R activity was significantly higher in $\mathrm{Fe} 0$ plants (Table 2) than in Fe120 plants.

In roots of chlorotic plants $\mathrm{P}$ and $\mathrm{Ca}$ contents were higher than in non-chlorotic plants (Table 3). Plants of Fe120 contained significantly higher amounts of total Fe (1873 $\mu$ g per plant) compared to Fe0 plants (1021 $\mu$ g per plant). Conversely, Fe0 plants accumulated more $\mathrm{Cu}$ and $\mathrm{Zn}$. As for all the remaining nutrients, contents were statistically similar (Table 3 ).

\subsection{Phase II}

After the vegetative rest (end of winter), the lowest values of leaf $\mathrm{Chl}$ were found in calcareous soil either Fe0 or Fe120 plants, in both kind of leaves (Fig. 1). Chl values were lower compared to those obtained in phase I, irrespective leaf type. The highest values 
Phase I

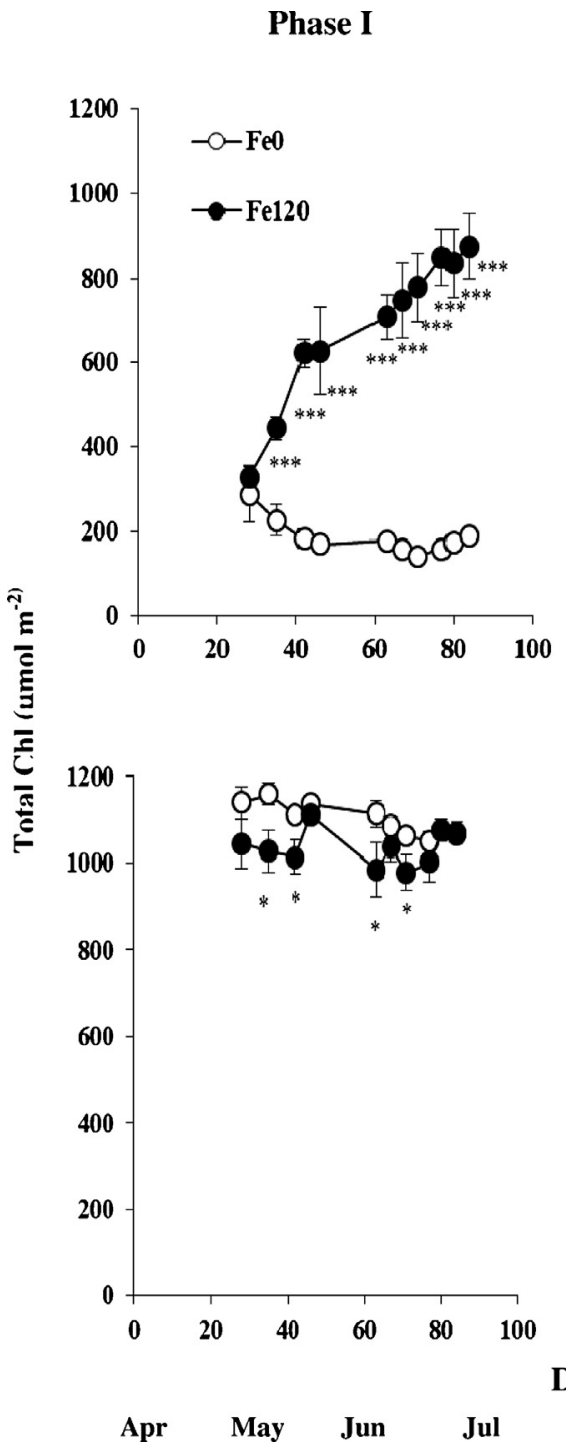

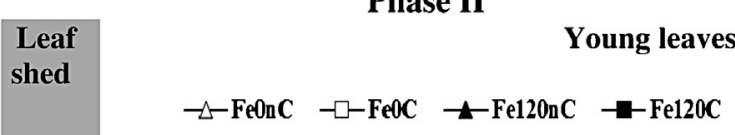

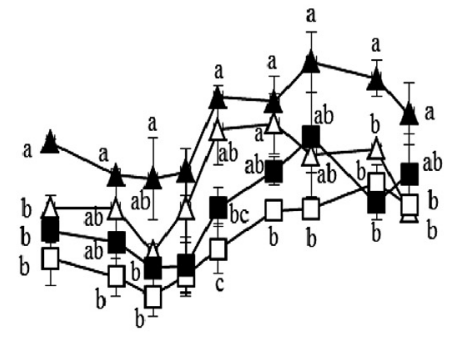

$\begin{array}{lllllll}340 \quad 360 & 380 & 400 & 420 & 440 & 460\end{array}$

Mature leaves

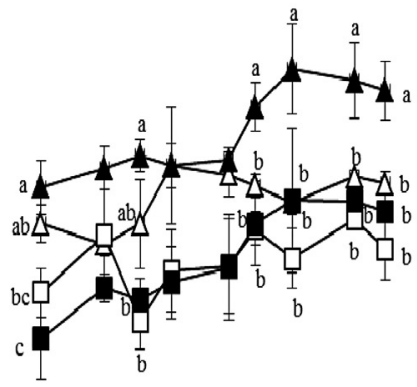

$\begin{array}{lllllll}340 \quad 360 & 380 & 400 & 420 & 440 & 460\end{array}$

Days of treatments

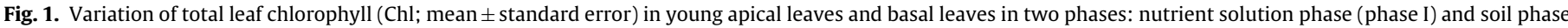

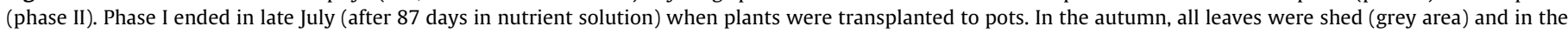
following April the first measurements were done at the beginning of phase II. Different letters indicate significant differences for $P<0.05$; $10<n<40$ for both phases.

of Chl were observed in mature leaves in phase I, even in Fe0 plants, and in Fe120nC plants in phase II throughout the experiment. Plants transplanted to the calcareous soil (C) had smaller shoot and root dry weights, irrespectively of the amount of Fe in nutrient solution during phase I (Table 2).

Plant height was only significantly smaller in the plants of the Fe0C treatment. As with Chl, root FC-R activities during phase II (Table 4) were in general lower than those observed in phase I (Table 2). The highest activity was registered in Fe120 plants grown in the calcareous soil ( $1.97 \mathrm{nmol} \mathrm{Fe} \mathrm{(II)} \mathrm{min}^{-1} \mathrm{~g}^{-1}$ of FW). Values in the remaining treatments were similar, with no significant differences between them. At the end of phase II (Figs. 2 and 3), the contents of macronutrients ( $\mathrm{N}, \mathrm{P}, \mathrm{K}, \mathrm{Mg}$ and $\mathrm{Ca}$ ) were higher in stems than in roots or leaves, while the micronutrients accumulated more in the roots, thus leading to a significant effect of plant organ (O) on all nutrients contents (Table 5).

Plants grown in the non-calcareous soil (nC), either grown without or with $120 \mu \mathrm{M}$ Fe in phase I, had consistent higher amounts of $\mathrm{N}, \mathrm{P}, \mathrm{K}, \mathrm{Mg}$ and Ca compared to plants grown in the calcareous soil in all parts except for Ca in roots (Fig. 2). The soil effect was therefore highly significant, but not the Fe treatments effects except on $\mathrm{Cu}$ and $\mathrm{Zn}$ contents (Table 5).
The differences in the contents of $\mathrm{N}, \mathrm{Mg}$ and $\mathrm{Ca}$ in stems were not significant but higher values of macronutrients were normally found in leaves and roots of the Fe0nC treatment. As for $\mathrm{Zn}$, Mn and Fe, the responses were similar, particularly for Fe (Fig. 3). In this case, statistical differences were observed between plants grown in each soil ( $\mathrm{nC}$ and $\mathrm{C}$ ). The exception was $\mathrm{Cu}$, since a greater accumulation was registered only in Fe0nC plants. In general, the interactions between the main factors (plant organs, soil and previous Fe level) were not significant (Table 5).

\section{Discussion}

Iron is not a component of $\mathrm{Chl}$ but it is required for the synthesis of protochlorophyllide from Mg-protoporphyrin (Miller et al., 1995). The sharp decrease in leaf Chl of young leaves during phase I and the appearance of Fe chlorosis confirms the poor tolerance of $P$. trifoliata to Fe stress (Castle et al., 2009; Forner-Giner et al., 2010). The depletion of leaf Chl, however, did not affect biomass accumulation in chlorotic plants, since the dry weight of roots as well as root to shoot ratio were not significantly different between treatments. This result was somewhat unexpected since Fe chlorosis usually reduces vegetative growth. However, Forner-Giner et al. 
Leaves

$\mathbf{N}$

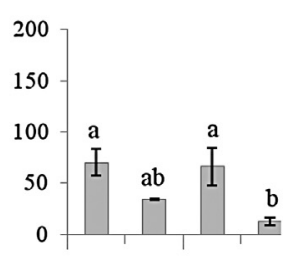

Stems

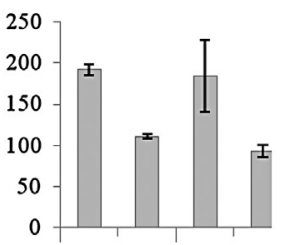

Roots

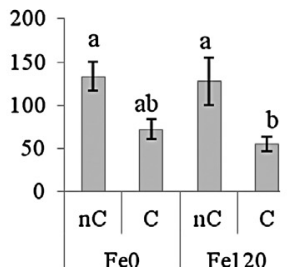

$\mathbf{P}$
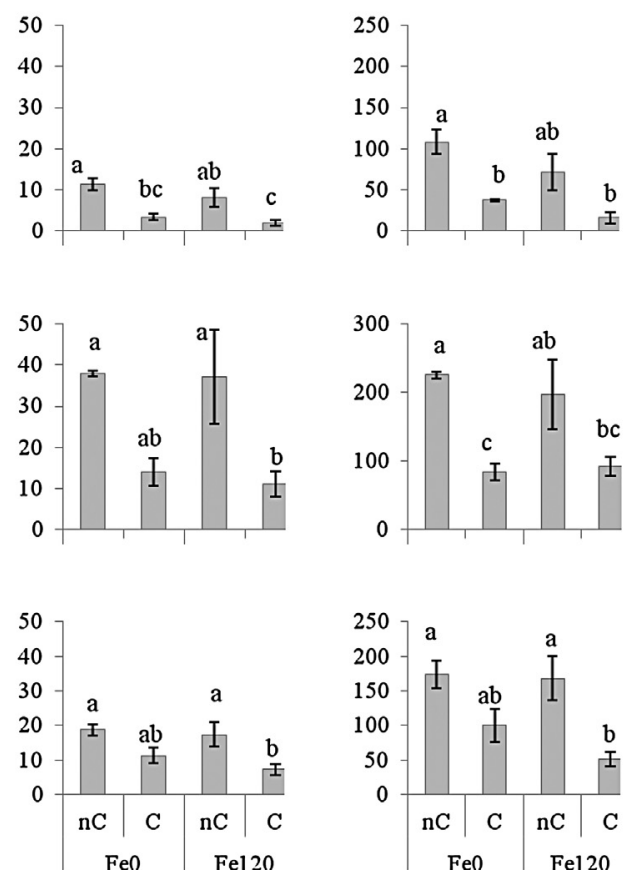

$\mathbf{K}$

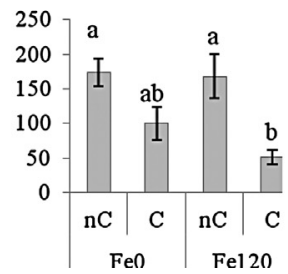

Mg
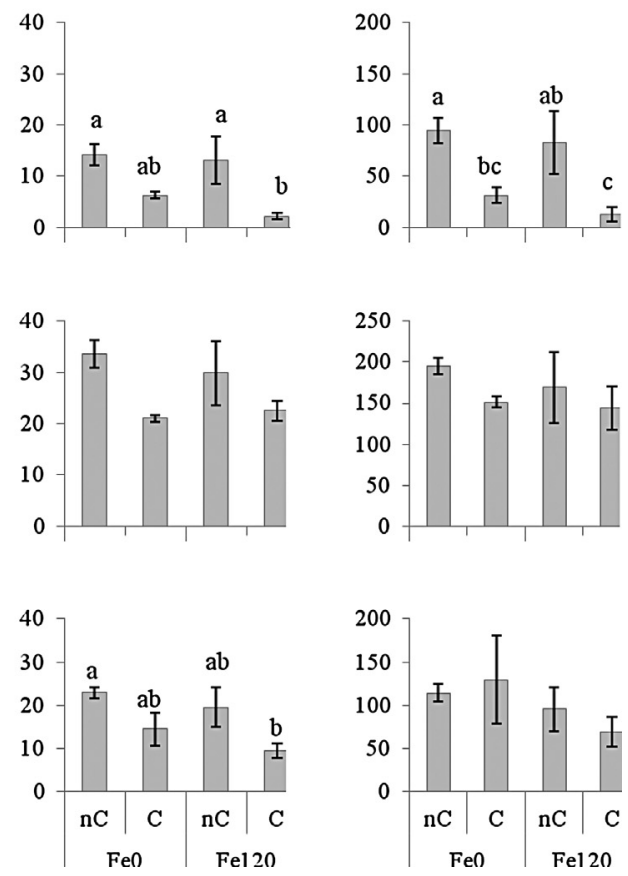

Fig. 2. Contents of macronutrients (in mg per organ) in different plant compartments at the end of phase II. Data are means \pm standard error. Different letters in columns indicate significant differences for $P<0.05$; at least $n=5$.

(2010) also found similar values of DW of roots and leaves of Poncirus plants grown with and without Fe in the irrigation solution, and this lack of variation was attributed to the short term of this experiment (60 days). In our case, it is possible that Fe endogenous pools from the nursery stage (about $900 \mu \mathrm{g}$ per plant at the beginning of phase I) and the high Chl values in basal mature leaves through the entire phase I were enough to ensure available active Fe to plants and photosynthesis rates during this phase.

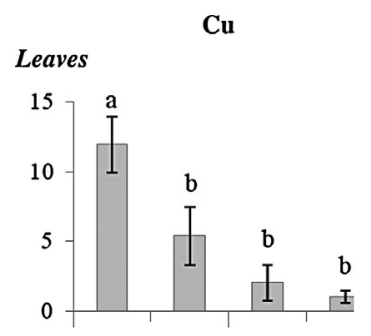

\section{Stems}

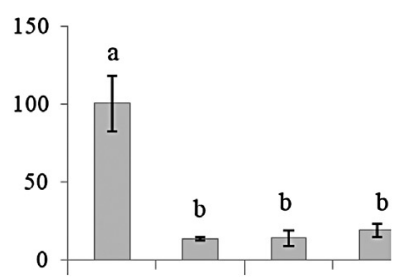

Roots

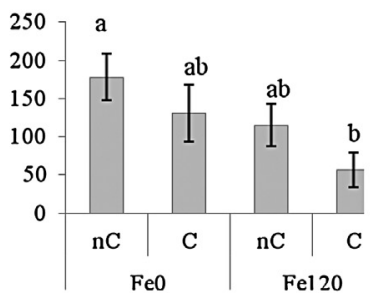

$\mathrm{Zn}$
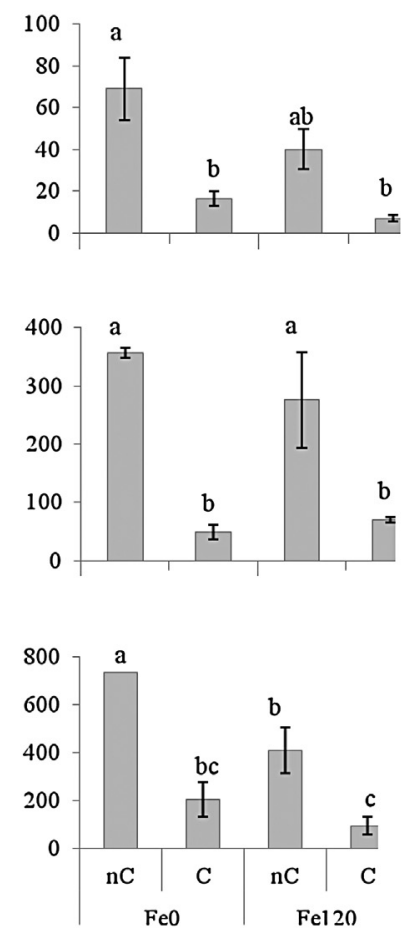

Mn

$\mathrm{Fe}$
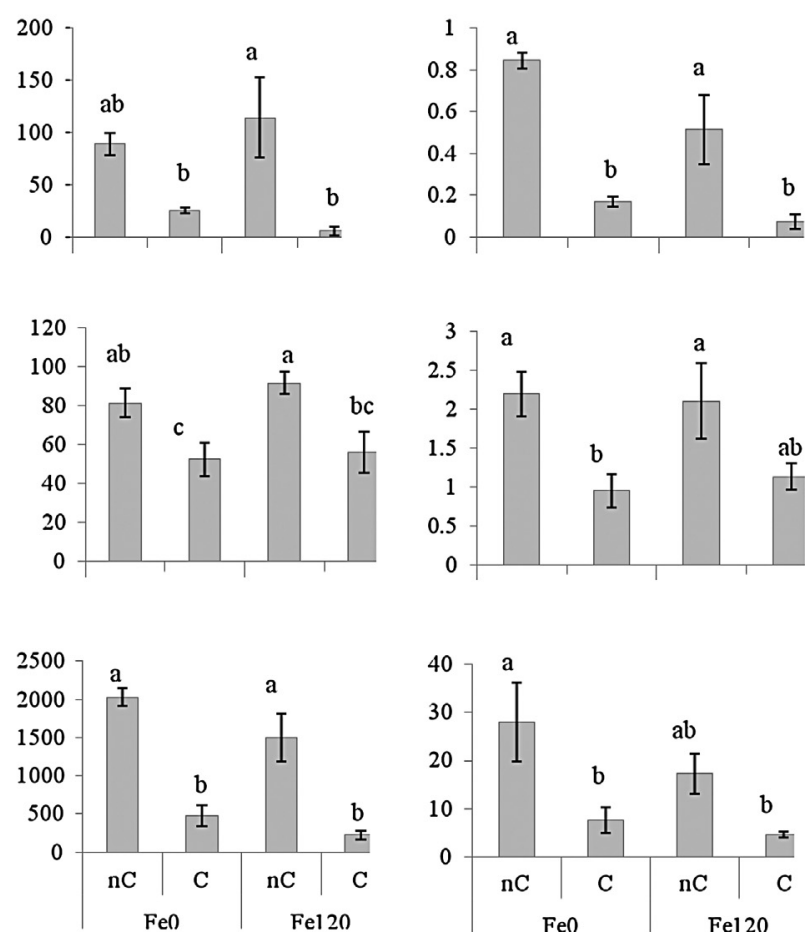

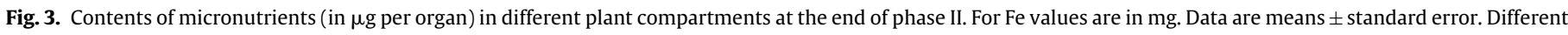
letters in columns indicate significant differences for $P<0.05$; at least $n=5$. 
Table 3

Nutrient content determined in roots and shoots of each treatment at the end of phase I (87 days in nutrient solution).

\begin{tabular}{|c|c|c|c|}
\hline & \multicolumn{2}{|l|}{ Treatments } & \\
\hline & $\mathrm{FeO}$ & Fe120 & \\
\hline \multicolumn{4}{|l|}{ (mg per organ) } \\
\hline Shoot & $165 \pm 22$ & $110 \pm 6$ & ns \\
\hline \multicolumn{4}{|l|}{$\mathrm{P}$} \\
\hline Shoot & $20 \pm 3$ & $15 \pm 0$ & ns \\
\hline \multicolumn{4}{|l|}{$\mathrm{K}$} \\
\hline Shoot & $106 \pm 14$ & $76 \pm 6$ & ns \\
\hline \multicolumn{4}{|l|}{$\mathrm{Mg}$} \\
\hline Shoot & $15 \pm 2$ & $10 \pm 0$ & ns \\
\hline Root & $6 \pm 1$ & $4 \pm 0$ & ns \\
\hline \multicolumn{4}{|l|}{$\mathrm{Ca}$} \\
\hline Shoot & $69 \pm 12$ & $44 \pm 2$ & ns \\
\hline \multicolumn{4}{|l|}{ ( $\mu$ g per organ) } \\
\hline \multicolumn{4}{|l|}{$\mathrm{Cu}$} \\
\hline Shoot & $59 \pm 4$ & $25 \pm 2$ & $* *$ \\
\hline Root & $75 \pm 4$ & $19 \pm 3$ & ${ }^{* * *}$ \\
\hline \multicolumn{4}{|l|}{$\mathrm{Zn}$} \\
\hline Shoot & $86 \pm 17$ & $54 \pm 2$ & ns \\
\hline Root & $131 \pm 4$ & $76 \pm 6$ & $* *$ \\
\hline \multicolumn{4}{|l|}{$\mathrm{Mn}$} \\
\hline Shoot & $138 \pm 31$ & $96 \pm 6$ & ns \\
\hline Root & $694 \pm 145$ & $437 \pm 51$ & ns \\
\hline \multicolumn{4}{|l|}{$\mathrm{Fe}$} \\
\hline Shoot & $439 \pm 109$ & $281 \pm 14$ & ns \\
\hline Root & $582 \pm 47$ & $1592 \pm 27$ & $* * *$ \\
\hline
\end{tabular}

Mean \pm standard error; ${ }^{*},{ }^{* *}$ or ${ }^{* * *}$ indicate, respectively: significant for $P<0.05,0.01$ or $P<0.001$ (ANOVA; $F$ test); at least $n=5$.

During phase II, Chl values in both leaf types were lower compared to phase I, possibly due to the physiological effort made by plants at the spring flush.

In general, the previous imposition of Fe stress triggered less Fe in roots tissues and our results confirm those reported in the literature for citrus (Pestana et al., 2004; Martínez-Cuenca et al., 2013), since total $\mathrm{Fe}$ in $\mathrm{Fe} 0$ roots $(582 \pm 81 \mu \mathrm{g} \mathrm{Fe}$ ) was significantly lower than in Fe120 plants $(1592 \pm 47 \mu \mathrm{g} \mathrm{Fe})$. The absence of Fe did not reduce the uptake of $\mathrm{N}, \mathrm{K}, \mathrm{Mg}$ or $\mathrm{Mn}$ in chlorotic plants, suggesting that under our experimental conditions major root uptake mechanisms were not severely affected which may also explain why the biomass did not decrease significantly. Interestingly, we found an increase of $\mathrm{P}$ and $\mathrm{Ca}$ in roots of Fe deficient plants at the end of phase II, which may be related to the accumulation of Fe-phosphate and $P$ compounds like phytate. In peach trees grown in the field and in sugar beet in hydroponics, the concentrations of all nutrients, with the exception of Fe, was also similar between chlorotic and green leaves after foliar application of $\mathrm{FeSO}_{4}$ (El-Jendoubi et al., 2011). In accordance, in the Prunus GF677 hybrid, the levels of Mn, $\mathrm{Zn}$ and $\mathrm{Cu}$ in leaves were higher in Fe deficient plants compared to
Table 5

Significance levels of each main factor and interactions for nutrient contents at the end of phase II.

\begin{tabular}{|c|c|c|c|c|c|c|c|c|c|}
\hline Main factors & $\mathrm{N}$ & $\mathrm{P}$ & $\mathrm{K}$ & $\mathrm{Mg}$ & $\mathrm{Ca}$ & $\mathrm{Cu}$ & $\mathrm{Zn}$ & Mn & $\mathrm{Fe}$ \\
\hline Substrate (S) & ** & *** & *** & $* *$ & $*$ & * & ** & $* *$ & $* *$ \\
\hline Fe treatments (Fe) & ns & ns & ns & ns & ns & * & * & ns & ns \\
\hline Plant organs $(\mathrm{O})$ & $* *$ & $* *$ & $* *$ & $* *$ & $* *$ & $* *$ & ** & $* *$ & $* *$ \\
\hline $\mathrm{S} \times \mathrm{Fe}$ & ns & ns & ns & ns & ns & ns & ns & ns & ns \\
\hline $\mathrm{S} \times \mathrm{O}$ & ns & ${ }_{*}^{*}$ & ns & ns & ns & ns & $* *$ & $* *$ & $* *$ \\
\hline $\mathrm{Fe} \times \mathrm{O}$ & ns & ns & ns & ns & ns & ns & * & ns & ns \\
\hline $\mathrm{S} \times \mathrm{Fe} \times \mathrm{O}$ & ns & ns & ns & ns & ns & ns & ns & ns & ns \\
\hline
\end{tabular}

controls (Jiménez et al., 2008), a response attributed to the role of non-specific transporters. The lack of Fe in the growing solution led to an increase of root $\mathrm{Cu}$ in strawberry (Pestana et al., 2013) and it has been reported that $\mathrm{Cu}$ and Fe have similar affinity to different enzymatic systems (Cohu and Pilon, 2007). Hence, under Fe deficiency, a metabolic shift occurs to enhance the reduction capacity resulting in a greater uptake of $\mathrm{Cu}$.

The activity of the FC-R also increased in chlorotic plants compared to control plants in phase I. This is a well-known response found in Strategy I dicots plants (Walker and Connolly, 2008) to increase the metabolically active Fe (II) in roots. In a different but complementary experiment, Pestana et al. (2012) registered an increase of root FC-R in Poncirus plants if a small concentration of $\mathrm{Fe}(1 \mu \mathrm{M} \mathrm{Fe})$ was added to the growing solution suggesting that the activation of this enzyme occurs under total absence or with a small Fe amount. This result should be interpreted with care as it may not be extrapolated to other crops. For example, in some Prunus rootstocks like 'Barrier' classified as Fe sensitive, in vivo enhancement of root FC-R activity was not observed under Fe deficiency conditions (Jiménez et al., 2008).

Taken together, the results indicate that plants of the Fe0 treatment activated well-known mechanisms and could thus be used to follow changes when transplanted to the two soils. Phase II was used to evaluate how plants would behave in a non-calcareous (slightly acid soil) and an alkaline calcareous soil. Is it possible to assume that the physiological adaptations of chlorotic plants would be an advantage in calcareous soils? P. trifoliata is a deciduous species (e.g. Agustí et al., 2002) and all leaves were shed during winter. Thus, the retranslocation of nutrients from leaves to stems or roots and its influence on the subsequent behaviour of both chlorotic and non-chlorotic plants must be taken into consideration. Nutrients that are very mobile in the phloem, like $\mathrm{K}$ and P, are retranslocated in deciduous trees (Shi et al., 2011) and also in evergreen trees (Correia and Martins-Loução, 1997) before leaf senescence and a considerable pool of nutrients become available for the spring flush. A different situation can be expected for nutrients that are not very mobile. In this respect, Shi et al. (2011) observed that leaf senescence did not lead to retranslocation of Fe and other micronutrients in deciduous trees, although these findings do not agree with results reported for oak (Abadía et al., 1996).

Table 4

Plant height, dry weight and ferric chelate-reductase (FC-R) activity ( $\mathrm{nmol} \mathrm{Fe}(\mathrm{II}) \mathrm{min}^{-1} \mathrm{~g}^{-1} \mathrm{FW}$ ) after the end of phase II.

\begin{tabular}{|c|c|c|c|c|c|c|c|c|}
\hline \multirow[b]{3}{*}{ Height $(\mathrm{cm})$} & \multicolumn{4}{|c|}{ Non-Calcareous soil } & \multicolumn{4}{|c|}{ Calcareous soil } \\
\hline & \multicolumn{2}{|l|}{$\mathrm{Fe} 0$} & \multicolumn{2}{|l|}{ Fe120 } & \multicolumn{2}{|l|}{$\mathrm{Fe} 0$} & \multicolumn{2}{|l|}{ Fe120 } \\
\hline & $78 \pm 4$ & $\mathrm{a}$ & $93 \pm 12$ & $\mathrm{a}$ & $47 \pm 1$ & $\mathrm{~b}$ & $66 \pm 6$ & $a b$ \\
\hline Shoot $(\mathrm{g})$ & $33 \pm 1$ & $\mathrm{a}$ & $32 \pm 10$ & $\mathrm{a}$ & $10 \pm 2$ & $\mathrm{~b}$ & $10 \pm 2$ & $\mathrm{~b}$ \\
\hline $\operatorname{Root}(\mathrm{g})$ & $12 \pm 2$ & $\mathrm{a}$ & $11 \pm 3$ & $\mathrm{ab}$ & $5 \pm 1$ & bc & $4 \pm 1$ & $\mathrm{c}$ \\
\hline Root/Shoot & $0.35 \pm 0.03$ & $\mathrm{~b}$ & $0.35 \pm 0.03$ & $\mathrm{~b}$ & $0.48 \pm 0.04$ & $\mathrm{a}$ & $0.38 \pm 0.06$ & $a b$ \\
\hline FC-R & $0.64 \pm 0.04$ & $\mathrm{~b}$ & $0.82 \pm 0.10$ & b & $0.69 \pm 0.19$ & $\mathrm{~b}$ & $1.97 \pm 0.26$ & $\mathrm{a}$ \\
\hline
\end{tabular}

Mean \pm standard error; Different letters in a row indicate significant differences for $P<0.05$; at least $n=5$. 
In our experiment, the presence of carbonate in the soil was a decisive factor for plant response. This was supported by the trends of leaf Chl, in young and mature leaves which showed higher values in both Fe0nC and Fe120nC treatments. In grapevine vegetative growth also decrease with increasing proportion soil carbonate irrespective of the Fe substrate availability (Díaz et al., 2009). At the end of our experiment (440 days), the adequate conditions of the non-calcareous soil resulted in a good vegetative growth, a down regulation of the FC-R activity in roots, and a high uptake of macro and micronutrients. The risk of Fe chlorosis in different crops (Reyes et al., 2006; Díaz et al., 2010) may be estimated by labile soil Fe and carbonates. Both soils had similar levels of Fe oxides $\left(\mathrm{Fe}_{\mathrm{ox}}\right)$ but the ratio $\left(\mathrm{Fe}_{\mathrm{ox}} / \mathrm{ACCE}\right) \times 10^{4}$ seemed a good indicator of $\mathrm{Fe}$ chlorosis in both $\mathrm{Fe} 0$ and $\mathrm{Fe} 120$ plants, as it was related with a major depression of nutrient uptake by plants which grew previously with a high supply of Fe (Fe120 in phase I). Even with this soil effect, we must consider the hypothesis of a "selective stress memory" present in plants of $\mathrm{Fe} 0$ from phase I. Is it possible to take advantage from it? In the absence of carbonates $(\mathrm{nC})$ plants responded positively for most of the macro and micronutrients contents. Those that grew under Fe deficiency $(\mathrm{Fe} 0$ ) during phase I were able to accumulate at least similar amount of Fe from the soil in phase II comparing to Fe120 plants, which may support the existence of a stress memory in Fe0 plants. This response was also observed for the other metals ( $\mathrm{Zn}$, $\mathrm{Mn}$ and in particular $\mathrm{Cu}$ ). This means that some internal signalling was operating during the entire phase II. Nevertheless, the Fe accumulated in plants of $\mathrm{Fe} 0$ was probably physiologically inactive, thus explaining the low $\mathrm{Chl}$ in leaves of Fe0nC treatments.

As pointed out by Abadía et al. (2011), signalling pathways and Fe sensors in regulatory mechanisms are still poorly understood. The knowledge of these mechanisms would open up the possibility of using non-tolerant genotypes in calcareous soils, without the need to apply Fe fertilizers.

\section{Conclusions}

Plants grown without Fe in the solution developed well-known adaptation mechanisms. Root FC-R was enhanced and there was an uptake of metals ( $\mathrm{Cu}, \mathrm{Zn}$ and $\mathrm{Mn}$ ) as an alternative to $\mathrm{Fe}$ at the end of phase I. The hypothesis that this multiple response mechanisms may be a part of a selective stress memory that could help the plants to cope with adverse field conditions was assessed in our study. It seems that metal homeostasis was changed, particularly in what concerns to the uptake of $\mathrm{Fe}$ and $\mathrm{Cu}$, and their mobilization in all plant compartments. A high Fe supply during the nutrient solution phase and the enrichment of the Fe pools were apparently, not an advantage to plants when facing the conditions of a calcareous soil. Ultimately, those plants did not exhibit a better performance comparing to $\mathrm{Fe} 0$ plants.

The adaptation mechanisms and the nutritional hardening in the low Fe supply might be used as a tool to cope with different soil constraints. Management of specific nutritional balance at nursery level may be a tool for a successful field and may potentiate the performance of rootstocks in different types of soils. Further experiments must be carried out with other tolerant and non-tolerant citrus rootstocks to validate these results.

\section{Acknowledgements}

This study was funded by the National Project from the FCT-the Foundation for Science and Technology: PTDC/AGRALI/100115/2008 and FEDER Funds through the Operational Programme for Competitiveness Factors-COMPETE. It also received funding from FCT as part of the Strategic Project: PEstC/AGR/UI0115/2011. The authors wish to thank "Associação de
Viveiristas de Coimbra" from Portugal for providing the Poncirus plants. I. Díaz was supported by a grant from "IV plan propio" from the University of Seville, Spain. F. Gama is thankful to FCT for the PhD Grant SFRH/BD/89521/2012.

\section{References}

A.O.A.C., 1990. Association of Official Agricultural Chemists. Official Methods of Analysis, Washington D.C.

Abadía, A., Morales, F., Montañés, L., MontSerrat, G., Abadía, J., 1996. Marcescence and senescence in a submediterranean oak (Quercus subpyrenaica E.H. del Villar): photosynthetic characteristics and nutrient composition. Plant Cell Environ. 19 685-694.

Abadía, J., Vázquez, S., Rellán-Álvarez, R., El-Jendoubi, H., Abadía, A., ÁlvarezFernández, A., López-Millán, A.F., 2011. Towards a knowledge-based correction of iron chlorosis. Plant Physiol. Biochem. 49, 471-482.

Agustí, M., Martínez-Fuentes, A., Mesejo, C., 2002. Citrus fruit quality. Physiological basis and techniques of improvement. Agrociencia VI, 1-16.

Álvarez-Fernández, A., Melgar, J.C., Abadía, J., Abadía, A., 2011. Effects of moderate and severe iron deficiency chlorosis on fruit yield, appearance and composition in pear (Pyrus communis L.) and peach (Prunus persica (L.) Batsch). Environ. Exp. Bot. 71, 280-286.

Bienfait, H.F., Bino, R.J., Van der Blick, A.M., Duivenvoorden, J.F., Fontaine, J.M., 1983. Characterization of ferric reducing activity in roots of Fe-deficient Phaseolus vulgaris. Physiol. Plant. 59, 196.

Bouyoucos, G.J., 1962. Hydrometer method improved for making particle size analyses of soils. Agron. J. 54, 464-465

Castle, W.S., Nunnallee, J., Manthey, J.A., 2009. Screening citrus rootstocks and related selections in soil and solution cutlure for tolerance to low-iron stress. HortScience 44, 638-645.

Chouliaras, V., Therios, I., Molassiotis, A., Diamantidis, G., 2004. Iron chlorosis in grafted sweet orange (Citrus sinensis L.) plants: physiological and biochemical responses. Biol. Plant. 48, 141-144.

Cohu, C.M., Pilon, M., 2007. Regulation of superoxide dismutase expression by copper availability. Physiol. Plant. 129, 747-755.

Correia, P.J., Martins-Loução, M.A., 1997. Leaf nutrient variation in mature carob (Ceratonia siliqua) trees in response to irrigation and fertilization. Tree Physiol. 17, 813.

Correia, P.J., Lopes, D., Duarte, A., Gama, F., Saavedra, T., Pestana, M., 2014. Is there a relationship between ferric chelate-reductase activity in roots of Poncirus trifoliata and leaf chlorophyll contents? In: 12th International Citrus Congress, Valencia, Spain, p. 329.

Díaz, I., del Campillo, M.C., Cantos, M., Torrent, J., 2009. Iron deficiency symptoms in grapevine as affected by the iron oxide and carbonate contents of mode substrates. Plant Soil 322, 293-302.

Díaz, I., Barrón, V., del Campillo, M.C., Torrent, J., 2010. Testing the ability of vivianite to prevent iron deficiency in pot-grown grapevine. Sci. Hortic. 123 464-468.

Drouineau, G., 1942. Dosage rapide du calcaire actif du sol: nouvelles données sur la separation et la nature des fractions calcaires. Ann. Agron. 12, 441.

El-Jendoubi, H., Melgar, J.C., Álvarez-Fernández, A., Sanz, M., Abadía, A., Abadía, J. 2011. Setting good practices to assess the efficiency of iron fertilizers. Plant Physiol. Biochem. 49, 483-488.

Forner-Giner, M.A., Llosá, M.J., Carrasco, J.L., Perez-Amador, M.A., Navarro, L., Ancillo G., 2010. Differential gene expression analysis provides new insights into the molecular basis of iron deficiency stress response in the citrus rootstock Poncirus trifoliata (L.) Raf. J. Exp. Bot. 61, 483

Gogorcena, Y., Abadía, J., Abadía, A., 2004. A new technique for screening ironefficient genotypes in peach rootstocks: elicitation of root ferric chelate reductase by manipulation of external iron concentrations. J. Plant Nutr. 27, 1

Jiménez, S., Pinochet, J., Abadía, A., Moreno, M.A., Gogorcena, Y., 2008. Tolerance response to iron chlorosis of Prunus selections as rootstocks. HortScience 43, 304-309.

Jiménez, S., Morales, F., Abadía, A., Abadía, J., Moreno, M.A., Gogorcena, Y., 2009 Elemental 2-D mapping and changes in leaf iron and chlorophyll in response to iron re-supply in iron-deficient GF 677 peach-almond hybrid. Plant Soil 315 93-106.

Lucena, J.J., 2009. El empleo de complejantes y quelatos en la fertilización de micronutrientes. Ceres 56, 527.

Martínez-Cuenca, M.R., Iglesias, D.J., Talón, M., Abadía, J., López-Millán, A., PrimoMillo, E., Legaz, F., 2013. Metabolic responses to iron deficiency in roots of Carrizo citrange [Citrus sinensis (L.) Osbeck $\times$ Poncirus trifoliata (L.) Raf.]. Tree Physiol. 33, 320-329

Mehra, O.P., Jackson, M.L., 1960. Iron oxide removal from soils and clays by a dithionite-citrate system buffered with sodium bicarbonate. Clays Clay Miner. 7, 317-327.

Mehlich, A., 1984. Determination of cation-and anion-exchange properties of soils Soil Sci. 66, 429

Miller, G.W., Huang, I.J., Welkie, G.W., Pushnik, J.C., 1995. Function of iron in plants with special emphasis on chloroplasts and photosynthetic activity. In: Abadía, J. (Ed.), Iron Nutrition in Soils and Plants. Kluwer Academic Publishers, Dordrecht Netherlands, pp. 19-28. 
Olsen, R.A., Sommers, L.E., 1982. Phosphorus. In: Page, A.L., Miller, R.H., Keeney, D.R. (Eds.), Methods of Soil Analysis. Soil Science Society of America Inc., Madison, WI, pp. 403-430 (Part 2)

Pestana, M., de Varennes, A., Faria, E.A., 2003. Diagnosis and correction of iron chlorosis in fruit trees: a review. Food Agric. Environ. 1, 46-51.

Pestana, M., de Varennes, A., Faria, E.A., 2004. Lime-induced iron chlorosis in fruit trees. In: Dris, R., Jain, S.M. (Eds.), Production Practices and Quality Assessment of Food Crops: Plant Mineral Nutrition and Pesticide Management, 2. Kluwer Academic Publishers, Dordrecht, The Netherlands, pp. 171-215.

Pestana, M., de Varennes, A., Abadía, J., Faria, E.A., 2005. Differential tolerance to iron deficiency of citrus rootstocks grown in nutrient solution. Sci. Hortic. 104, 25-36.

Pestana, M., Correia, P.J., David, M., Abadía, A., Abadía, J., de Varennes, A., 2011a Response of five citrus rootstocks to iron deficiency. J. Plant Nutr. Soil Sci. 174, 837-846.

Pestana, M., Domingos, I., Gama, F., Dandlen, S., Miguel, M.G., Castro Pinto, J., de Varennes, A., Correia, P.J., 2011b. Strawberry recovers from iron chlorosis after foliar application of a grass-clipping extract. J. Plant Nutr. Soil Sci. 174, 473-479.

Pestana, M., Gama, F., Saavedra, T., Varennes, A. de, Correia, P.J., 2012. The root ferricchelate reductase of Ceratonia siliqua (L.) and Poncirus trifoliata (L.) Raf. respond differently to levels of iron. Sci. Hortic. 135, 65-67.
Pestana, M., Correia, P., Saavedra, T. Gama, F., Dandlen, S., Nolasco, G., de Varennes, A., 2013. Root ferric chelate reductase is regulated by iron and copper in strawberry plants. J. Plant Nutr. 36, 2035-2047.

Reyes, J.M., del Campillo, M.C., Torrent, J., 2006. Soil properties influencing iron chlorosis in grapevines grown in the Montilla-Moriles Area, Southern Spain. Commun. Soil Sci. Plant Anal. 37, 1723-1729.

Riehm, H., 1958. Die ammoniumlaktatessigsaure-methode zur bestimmung de leichtloslichen phosphosaure in karbonathaltigen boden. Agrochimica 3, 49.

Rombolà, A.D., Tagliavini, M., 2006. Iron Nutrition of Fruit Tree Crops. In: Barton, L., Abadia, J. (Eds.), Iron Nutrition in Plants and Rhizospheric Microorganisms. Springer, Netherlands, pp. 61-83.

Schwertmann, U., 1964. Differenzierung der eisenoxide des bodens durch extraktion mit ammoniumoxalat-lösung. Z. Pflanzenernähr. Bodenkd. 105, 194-202.

Shi, R., Bässler, R., Zou, C., Römheld, V., 2011. Is iron phloem mobile during senescence in trees? A reinvestigation of Rissmüller's finding of 1874. Plant Physiol. Biochem. 49, 489-493

Walker, E.L., Connolly, E.L., 2008. Time to pump iron: iron-deficiency-signaling mechanisms of higher plants. Curr. Opin. Plant Biol. 11, 530-535.

Walkley, A., Black, I.A., 1934. An examination of the Degtjareff method for determining soil organic matter and a proposed modification of the chromic acid titration method. Soil Sci. 37, 29. 